\title{
Effect of Ramadhan fasting on left ventricular systolic function in geriatric patients
}

Nurhay Abdurahman

\begin{abstract}
Abstrak
Puasa Ramadhan adalah kewajiban umat Islam, termasuk juga para usila. Untukmenilai apakah berpuasa Ramadhan pada usila akan mempengaruhi kinerja ventrikel kiri dilakukan penelitian prospektif pada 43 pasien geriatri di Poliklinik Geriatri Bagian Ilmu Penyakit Dalam FKUI-RSUPN Dr Cipto Mangunkusumo. Secara klinis pasien tidak menderita penyakit gagal jantung kongestif dan tidak minum obat-obatan yang mempengaruhi fungsi sistolik ventrikel kiri. Fraksi ejeksi diukur dengan ekokardiografi sewaktu berpuasa dan salu bulan sesudahnya. Empat pasien dikeluarkan dari penelitian karena data yang tidak lengkap, dan seorang lagi karena hasil ekokardiografinya tak dapat dinilai. Dari 39 pasien yang dievaluasi, 26 adalah laki-laki dan 13 wanita, dengan usia antara 60 sampai 82 tahun (usia rerata 68,31 $\pm 4,86$ tahun). Hasil : Fraksi ejeksi rerata selama bulan puasa Ramadhan 63,64 $\pm 6,93 \%$ (kisaran antara 50 sampai $82 \%$ ). Fraksi ejeksi rerata pasca puasa $64,10 \pm 7,28 \%$ (kisaran antara 50 sampai $79 \%$ ). Secara statistik tak didapatkan perbedaan yang bermakna. Kesimpulan : Puasa Ramadhan sebulan penuh tidak menurunkan fraksi ejeksi pada orang usia lanjut.
\end{abstract}

\begin{abstract}
Ramadhan fasting is compulsory for every Moslem, including the aged. To assess whether fasting would adversely affect the left ventricular performance, 43 elderly patients of our Geriatry Clinic, Department of Internal Medicine, Faculty of Medicine, University of Indonesia, Dr. Cipto Mangunkusumo Hospital were enrolled in the study. Patients with congestive heart failure or on any medication affecting left ventricular systolic function were excluded. Ejection fraction was measured with echocardiography during the fasting month and again upon its completion. Three patients were dropped out due to insufficiency of the data obtained and one other patient had an uninterpretable echocardiographic result. The remaining 39 eligible patients consisted of 26 males and 13 females, with ages ranging from 60 to 82 years (mean $68.31 \pm 4.86$ years). Result: The mean ejection fraction during the fasting was $63.64 \pm 6.93 \%$ (range $50-82 \%$ ). At the completion of fasting, it was $64.10 \pm 7.28 \%$ (range 50-79\%). Statistically, there was no significant difference. Conclusion Ramadhan fasting for one whole month did not reduce ejection fraction in the elderly.
\end{abstract}

Keywords : Ramadhan fasting, geriatry, ejection fraction

Fasting during Ramadhan is a compulsary religious practice for every Moslem. ${ }^{1}$ Exceptions are for those who are sick or unfit to fast such as the aged. ${ }^{2}$ By definition during the Ramadhan fasting one has to restrict any food and fluid intake and refrain any sexual activities commencing from dawn to dusk. ${ }^{2}$ In the year 2000 the number of elderly people ( $>60$ years) in Indonesia is estimated to be 152.5 million. Majority numbers are Moslems and they may wish to accomplish the Ramadhan fasting.

Cardiovascular disease is the most frequent cause of morbidity and mortality in people above 65 years of

Division of Cardiology, Department of Internal Medicine, University of Indonesia Faculty of Medicine, Jakarta, Indonesia age. $^{3}$ Port et al in 1980 reported that age did not influence ejection fraction at rest. ${ }^{4}$ However during exercise, ejection fraction less than $60 \%$ was observed in $45 \%$ patients aged $>60$ years compared to $2 \%$ in the young age. The left ventricular systolic function measured at rest using echocardiography or radionuclide technique was not adversely influenced by age. ${ }^{5}$ Starness cs performed an experimental animal study with male rats to assess the effect of exercise and food restriction on cardiac performance. They found, that cardiac output showed significant improvement at 18 month of age in the groups: food restriction and exercise. $^{6}$

The effect of Ramadhan fasting on geriatric subjects has not been reported. It is still not known whether food and drink restriction for approximately 14 hours for one whole month would have negative influence on 
various parameters of cardiac performance. And if any change occured, which cardiac performance paramater will be effected, and to what extent can the alteration endanger the person and how to anticipate and treat it. Knowledge of the influence of Ramadhan fasting on cardiac performance in geriatric patients is important because despite of their good intention to devote their religion they must recognize their limits. During the fasting month, they are still required to carry out their daily routines so that any possible adverse affects on cardiac performance have to be anticipated.

The purpose of this study is to assess the effect of Ramadhan fasting on the left ventricular systolic function in geriatric patients.

\section{MATERIALS AND METHODS}

This study was conducted prospectively on all geriatrics treated in the outpatient clinic of the Division of Geriatry of the Department of Internal Medicine, Faculty of Medicine, University of Indonesia. Dr. Cipto Mangunkusumo Hospital, Jakarta, who had accomplished one full month of Ramadhan fasting. Other inclusion criteria were: those who had strong determination to do similarly this year, were in stable clinical condition, had no acute disease and consented to participate in the study. The excluding criteria were those who contracted congestive heart failure, or took any medication which might affect the left ventricular systolic function and those who did not comply to the study procedure as mentioned earlier.

To all eligible patients a complete anamnesis were taken including age, gender, medical history (cardiac disease, hypertension, diabetes mellitus). Patients were informed about the purpose of the study, the procedure, and the examinations that they would undergo. Each patient, underwent physical examination and echocardiography, during the second or third week of the Ramadhan fasting and subsequently an echocardiography using ATL echocardiography machine with mechanical CF $3.5 \mathrm{mHz}$ transduce was performed one month after. Recordings were attained on ultrasonic $\mathrm{CF}$ on paper with a speed of $50 \mathrm{~mm} / \mathrm{second}$. Echocardiographic data were interpreted by a cardiologist who was unaware of the patient's condition and analysis was done according to the recommendation by the American Society of Echocardiography.

\section{Operational definition}

Geriatric patients are those aged above 65 years and/or with more than one chronic/degenerative diseases.
Ramadhan fasting is an Islamic religion practice by which person must restrict any food and fluid intake and refrain from any sexual activities commencing from dawn to dusk. In Indonesia the duration lasts approximately 12 to 14 hours per day.

Left ventricular systolic function is measured with the following formula:

$$
\text { Ejection fraction }=\frac{\text { EDV }- \text { ESV }}{\text { EDV }} \times 100 \% \text {, where: }
$$

$\mathrm{EDV}=$ end diastolic volume

$\mathrm{ESV}=$ end systolic volume

\section{Statistical analysis}

The investigation results were reported in forms of mean value and standard deviation. Analysis of left ventricular systolic function during Ramadhan fasting compared with post-fasting performed by CF test with the assumption that variable distribution was normal. Limit of significance used was $5 \%$ and was considered significant if the $\mathrm{p}$ value was 0.05 .

\section{RESULTS}

Of the 43 geriatric patients recruited for the study 4 were excluded due to inadequate data ( 3 patients did not show up for echocardiographic investigation and one non-echogenic patient had an uninterpretable echocardiographic results). Analysis was done on the remaining 39 patients, consisting of 26 males and 13 females. Their ages ranged from 60 to 82 years with a mean age of $68.31 \pm 4.86$ years. Left ventricular systolic function (ejection fraction) ranged from $50 \%$ to $82 \%$ with a mean of $64.10 \pm 7.28 \%$. There was no statistically significant difference between fasting and post fasting groups $(\mathrm{p}>0.5)$ (table 1$)$.

Table 1. Comparison of systolic and diastolic left ventricle dimensions and ejection fraction between fasting and post-fasting groups

\begin{tabular}{llll}
\hline & Fasting & Post-fasting & p \\
\hline - LVEDD & $46.89 \pm 5.84$ & $47.26 \pm 5.17$ & NS \\
- LVESD & $30.59 \pm 5.16$ & $30.56 \pm 4.59$ & NS \\
- LVEF & $63.64 \pm 6.93$ & $64.10 \pm 7.28$ & NS \\
\hline
\end{tabular}

LVEDD $=$ Left Ventricular End Diastolic Diameter, LVESD $=$ Left Ventricular End Systolic Diameter, LVEF = Left Ventricular Ejection Fraction, $N=$ Not Significant 


\section{DISCUSSION}

Effect of Ramadhan fasting on left ventricular systolic function in the elderly has never been reported. In the elderly, the heart may undergo changes such as increase of collagen tissue, decrease of elastin tissue and increase of lipofuscin deposit on the muscle tissue. As a result, the contractility may be reduced. Cardiac output in the 70 year-old elderly is $2.51 / \mathrm{min} / \mathrm{m}^{2} \mathrm{com}$ pared to $3.71 / \mathrm{min} / \mathrm{m}^{2}$ in the 20 year-old young people. ${ }^{7}$ On exercise the cardiac index alteration showed similar trends as well. ${ }^{7}$ However, Ramadhan fasting may not result in organic changes due to the relatively short period of time.

Ballal et al. studied resting electrocardigraphic changes and during the treadmill stress procedure in 6 healthy people who completed the Ramadhan fasting. The study showed that pulse at rest during fasting was slower than during non-fasting ( $72.3 \pm 9.4$ vs $84.5 \pm$ $15.2 /$ minute) and the initial pulse load also declined $(103.4 \pm 26.5$ vs $91.6 \pm 16.5)$ whilst on further loading there was no pulse reduction. ${ }^{8}$ This suggested that physical fitness during fasting was similar even though at the initial loading it was better tolerated.

Our study showed that fasting did not cause significant decline in the ejection fraction in the elderly. Fasting is assumed to reduce free radical production and this will cause a positive impact in the human body.

\section{Acknowledgement}

To Dr Lukman Hakim and Dr Idrus Alwi, for their assistance in this study, to the division of Geriatry, Department of Internal Medicine, Medical School University of Indonesia, Dr. Cipto Mangunkusumo Hospital, for providing the study patients and also to miss Nurlaila for help in manuscript preparation, the author extended his sincere gratitude.

\section{REFERENCES}

1. Al-Qur' an, surat Al-Baqarah ayat 183.

2. Qardlawi Y. Fiqh puasa. Jakarta, PT Raja Grafindo Persada, 1997.

3. Wei JY. Age and the cardiovascular system. N Engl J Med, 1992; 327:1735-9.

4. Port S, Cobb FR, Coleman RE, Jones RH. Effect of age on the response of the left ventricular ejection fraction in exercise. N Engl J Med, 1980; 303:1133-7.

5. Fleg JL. Alteration in cardiovascular structure and function with advancing age. Am J Cardiol, 1986;33C-44C.

6. Starnes JW, Rumsey WL. Cardiac energetics and performance of exercise and food restricted rats during again. Am J Physiol, 1988; 254:H599-H608.

7. Kennedy RD, et al. Physiology of aging of the heart. In: Noble, Rothbaum, eds. Geriatric Cardiology. Philadelphia, Davis Coy, 1981:1-8.

8. Ballal M, Bakir SM. Effect of Ramadhan fasting on physical fitness. JAMA, 1993; 25:117-9. 